\title{
Biographies of international women leaders in neurosurgery
}

\author{
*Stephanie M. Casillo, BS, ${ }^{1}$ Anisha Venkatesh, BS, ${ }^{1}$ Nallammai Muthiah, BS, ${ }^{1}$ Nitin Agarwal, MD, \\ Teresa Scott, MBBS, MRCS, ${ }^{2}$ Rossana Romani, MD, PhD, FRCS, ${ }^{3}$ Laura L. Fernández, ${ }^{4}$ \\ Sarita Aristizabal, ${ }^{4}$ Elizabeth E. Ginalis, MD, ${ }^{5}$ Ahmad Ozair, ${ }^{6}$ Vivek Bhat, ${ }^{7}$ Arjumand Faruqi, ${ }^{6}$ \\ Ankur Bajaj, MCh, ${ }^{8}$ Abhinav Arun Sonkar, MS, FRCS, ${ }^{9}$ Daniel S. Ikeda, MD, ${ }^{10}$ \\ E. Antonio Chiocca, MD, PhD, ${ }^{11}$ Russell R. Lonser, MD, ${ }^{12}$ Tracy E. Sutton, ${ }^{12}$ \\ John M. McGregor, MD, ${ }^{12}$ Gary L. Rea, MD, PhD, ${ }^{12}$ Victoria A. Schunemann, MD,13 \\ Laura B. Ngwenya, MD, PhD, ${ }^{14}$ Evan S. Marlin, MD, ${ }^{15}$ Paul N. Porensky, MD, ${ }^{16}$ \\ Ammar Shaikhouni, MD, PhD, ${ }^{17}$ Kristin Huntoon, DO, PhD, ${ }^{18}$ David Dornbos III, MD, ${ }^{19}$ \\ Andrew B. Shaw, MD, ${ }^{20}$ Ciarán J. Powers, MD, PhD, ${ }^{12}$ Jacob M. Gluski, BSc, ${ }^{21}$ \\ Lauren G. Culver, BSc, ${ }^{21}$ Alyssa M. Goodwin, BSc, ${ }^{21}$ Steven Ham, DO, ${ }^{21,22}$ \\ Neena I. Marupudi, MD, MS, ${ }^{21,22}$ Dhananjaya I. Bhat, MCh(Neurosurgery), ${ }^{23}$ \\ Katherine M. Berry, MD, ${ }^{24}$ Eva M. Wu, MD, ${ }^{24}$ and Michael Y. Wang, MD ${ }^{24}$
}

\begin{abstract}
${ }^{1}$ Department of Neurological Surgery, University of Pittsburgh Medical Center, Pittsburgh, Pennsylvania; ${ }^{2}$ Department of Neurosurgery, University Hospitals Coventry and Warwickshire, Coventry, Warwickshire; ${ }^{3}$ Department of Neurosurgery, Southampton University Hospital NHS Foundation Trust, Southampton, United Kingdom; ${ }^{4}$ Faculty of Medicine, El Bosque University, Semillero Investigación Neurotrauma, Group of Investigation INUB-MEDITECH, Institute of Neuroscience and Neurosurgery, El Bosque University, Bogotá, Colombia; ${ }^{5}$ Department of Neurological Surgery, Rutgers Robert Wood Johnson Medical School, New Brunswick, New Jersey; ${ }^{6}$ Faculty of Medicine, King George's Medical University, Lucknow; ${ }^{7}$ Faculty of Medicine, St. John's Medical College, Bangalore; ${ }^{8}$ Department of Neurosurgery, King George's Medical University, Lucknow; ${ }^{9}$ Department of General Surgery, King George's Medical University, Lucknow, India; ${ }^{10}$ Department of Surgery, US Naval Hospital Okinawa, Japan; ${ }^{11}$ Department of Neurosurgery, Brigham and Women's Hospital, Boston, Massachusetts; ${ }^{12}$ Department of Neurosurgery, The Ohio State University Wexner Medical Center, Columbus, Ohio; ${ }^{13}$ Department of Neurological Surgery, Thomas Jefferson University Hospitals, Philadelphia, Pennsylvania; ${ }^{14}$ Department of Neurosurgery and Department of Neurology and Rehabilitation Medicine, University of Cincinnati, Ohio; ${ }^{15}$ Department of Neurosurgery, St. Luke's University Hospital, Bethlehem, Pennsylvania; ${ }^{16}$ Service of Neurosurgery, Naval Medical Center San Diego, California; ${ }^{17}$ Division of Pediatric Neurological Surgery, Nationwide Children's Hospital, Columbus, Ohio; ${ }^{18}$ Department of Neurosurgery, The University of Texas MD Anderson Cancer Center, Houston, Texas; ${ }^{19}$ Department of Neurosurgery, Semmes Murphey Clinic and University of Tennessee Health Science Center, Memphis, Tennessee; ${ }^{20}$ Department of Neurosurgery, Baptist Medical Center, Jacksonville, Florida; ${ }^{21}$ Department of Neurosurgery, Wayne State University School of Medicine, Detroit; ${ }^{22}$ Department of Neurosurgery, Children's Hospital of Michigan, Detroit, Michigan; ${ }^{23}$ Department of Neurosurgery, Aster RV Hospital, Bangalore, India; and ${ }^{24}$ Department of Neurological Surgery, University of Miami Miller School of Medicine, Miami, Florida
\end{abstract}

We received so many biographies of women neurosurgery leaders for this issue that only a selection could be condensed here. In all of them, the essence of a leader shines through. Many are included as "first" of their country or color or other achievement. All of them are included as outstanding - in clinical, academic, and organized neurosurgery. Two defining features are tenacity and service. When faced with shocking discrimination, or numbing indifference, they ignored it or fought

ABBREVIATIONS ABNS = American Board of Neurological Surgery; WINS = Women in Neurosurgery.

SUBMITTED January 5, 2021. ACCEPTED January 7, 2021.

INCLUDE WHEN CITING DOI: 10.3171/2021.1.FOCUS201096

*S.M.C., T.S., L.L.F., S.A., E.E.G., A.O., D.S.I., J.M.G., N.I.M., D.I.B., and K.M.B. share first authorship of this work. 
valiantly. When choosing their life's work, they chose service, often of the most neglected-those with pain, trauma, and disability. These women inspire and point the way to a time when the term "women leaders" as an exception is unnecessary.

- Katharine J. Drummond, MD, on behalf of this month's topic editors

https://thejns.org/doi/abs/10.3171/2021.1.FOCUS201096

KEYWORDS biography; women; international

\section{Dorothy Klenke Nash, MD}

\section{Stephanie M. Casillo, BS, Anisha Venkatesh, BS, Nallammai Muthiah, BS, and Nitin Agarwal, MD}

Dr. Dorothy Klenke Nash (1898-1976), the first female neurosurgeon in the United States, declared that "we must learn to live within the limits of our ability but to the hilt of our capacity." ${ }^{5}$

Dorothy A. Klenke (Fig. 1) earned her medical degree

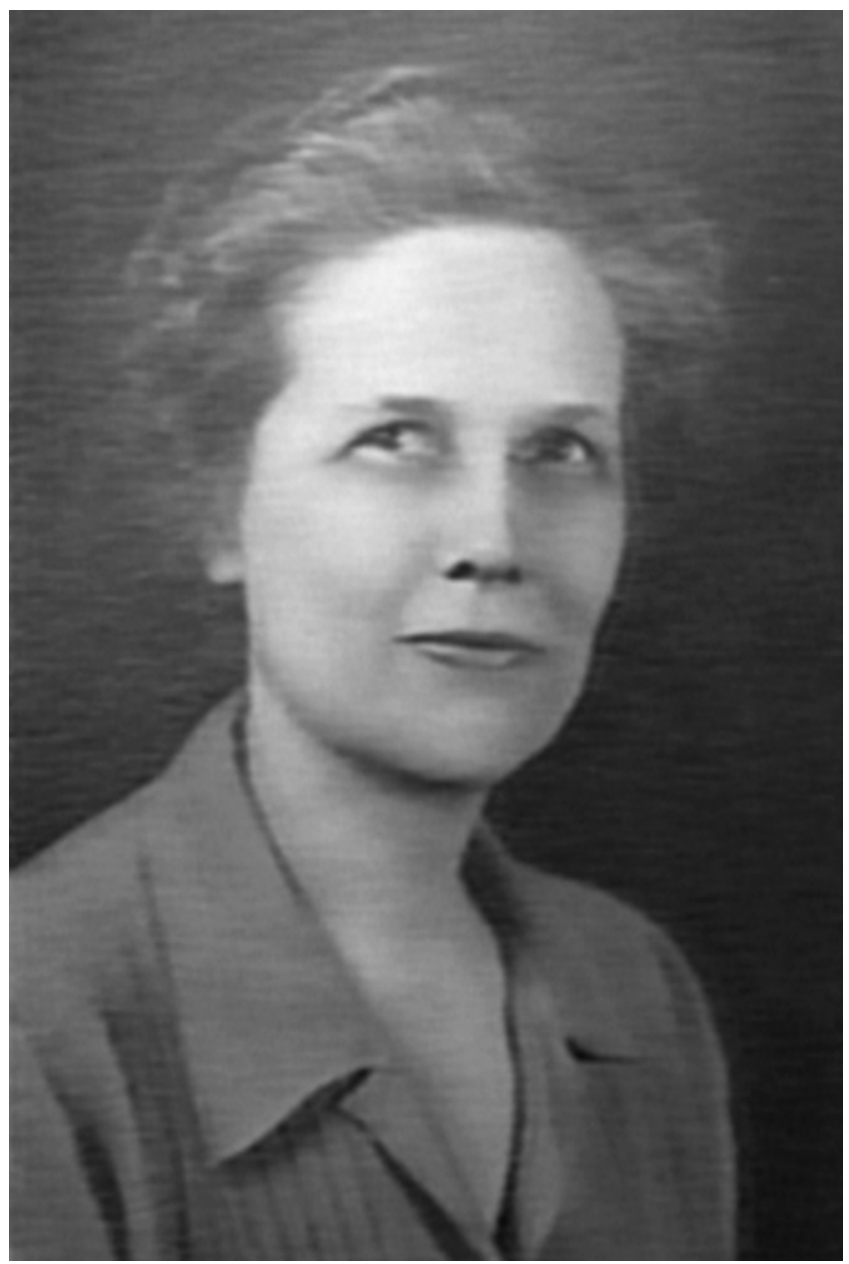

FIG. 1. Photograph of Dr. Dorothy Klenke Nash. Shortly after her appointment as senior surgeon at St. Margaret's Hospital in 1942, Dr. Klenke Nash joined the University of Pittsburgh Department of Neurosurgery and became an instructor at the University of Pittsburgh School of Medicine. Public domain image obtained from the University of Pittsburgh Department of Neurosurgery website. from Columbia College of Physicians and Surgeons in 1928. She completed neurosurgical residency training at the Neurological Institute of New York in 1925 and subsequently joined the staff as an assistant attending surgeon. ${ }^{1}$ During this appointment, Dr. Klenke contributed to the advancement of neurosurgical practice through academic research. In "A study of the spinal fluid pressure in the differential diagnosis of diseases of the spinal cord" (1928), Drs. Byron Stookey and Dorothy A. Klenke advocated for the use of lumbar manometry at the bedside for differentiation of spinal cord tumors versus intrinsic disease to ensure appropriate and timely surgical intervention. ${ }^{2}$ In "Experimental convulsions following lesions of the tuber cinereum" (1933), Drs. S. Bernard Wortis and Dorothy A. Klenke disproved the contemporary theory that there existed a singular anatomical "convulsogenic zone."3

Dorothy A. Klenke married Charles B. Nash (18801945) on May 9, 1931, and gave birth to their first child, George, in 1932. Shortly thereafter, the family relocated to Pittsburgh, and the couple welcomed their second child, Dorothy, in 1936. Unfortunately, Dr. Klenke Nash was unable to secure a surgical appointment following this move. Instead, she contributed to the war efforts, working at a military hospital, teaching first aid at the Red Cross, and volunteering at the local blood bank. It was at this blood bank that Dr. Klenke Nash had a chance meeting with Dr. Morris A. Slocum (1889-1950), chief of general surgery at St. Margaret's Hospital, who offered her a position as an attending neurological surgeon at St. Margaret's Hospital. Following this appointment, Dr. Klenke Nash joined the inaugural Department of Neurological Surgery at the University of Pittsburgh under Dr. Stuart N. Rowe (1905-1984) and became an instructor of neurosurgery at the University of Pittsburgh School of Medicine. ${ }^{4}$

Dr. Dorothy Klenke Nash was extensively involved in her community, helping found the United Cerebral Palsy Association of Western Pennsylvania and serving as the cochair of the 1953 awareness campaign for cerebral palsy for the Allegheny County chapter. ${ }^{5,6}$ She also helped found the Mental Health Society of Allegheny County, acted as the first female president of the Pittsburgh Neuropsychiatric Society, and served as the chairman for the Citizens Committee 1957 Conference on Mental Health. ${ }^{7}$ Dr. Klenke Nash was named to the Distinguished Daughters of Pennsylvania in 1952 and would later serve as president of this organization. In 1957, she earned the Minerva Award from the Women's Auxiliary of Mercy Hospital and was recognized as one of the Pittsburgh Post-Gazette's 10 Women of the Year. At this time, she was the only female member of the American Board of Neurological Surgery 
(ABNS). ${ }^{8}$ She received an honorary citation from the undergraduate institution Bryn Mawr College in 1960 and a commemorative medallion from the Columbia College of Physicians and Surgeons in 1968. ${ }^{5}$

Dr. Dorothy Klenke Nash retired from neurosurgical practice in 1965 and died on March 5, 1976, at the age of 77 years.

\section{Disclosures}

Dr. Agarwal: royalties from Thieme Medical Publishers.

\section{Correspondence}

Nitin Agarwal: agarwaln@upmc.edu.

\section{Diana Beck}

\section{Teresa Scott, MBBS, MRCS, and Rossana Romani, MD, PhD, FRCS}

Early in the last century, when neurosurgery was in its infancy, there were virtually no female neurosurgeons. Perhaps the first, certainly in the United Kingdom and quite likely in the world, was Ms. Diana Beck. ${ }^{9}$ Born in 1902, she studied medicine at the London School of Medicine for Women and, very unusual for that time, decided to specialize in neurosurgery, doing her apprenticeship in Oxford. She completed her neurosurgical training under the mentorship of Sir Hugh Cairns, one of the fathers of British neurosurgery and a pupil of Harvey Cushing's.

After a number of short postings in the early years of World War II, she served as an advisor for the Emergency Medical Service in southwest England, based in Bristol. Eventually, she settled in London and was appointed consultant neurosurgeon at the Royal Free Hospital in 1943.

She was no radical feminist, determined to topple the male-dominated structures in society as a whole and medicine in particular. Rather, she was extremely competent, with a particular aptitude for research and with outstanding teaching skills. Her competence was evident in the research she did and in her ability to take on pioneering operations at a time when understanding of the brain and neurosurgery was rudimentary. One of her more renowned patients was A. A. Milne, the author of Winnie the Pooh. She operated on him in 1952 after he suffered a stroke. As for her teaching skills, they were much appreciated by students who were ready to sacrifice their weekends to attend her ward rounds. There is no doubt that she would have approved of the "new" National Health Service (NHS) approach of putting the patient at the center of their care plan.

Ms. Beck never married or had children and died at the early age of 53 years, following a myasthenic crisis for which she underwent a thymectomy and subsequently developed a fatal pulmonary embolism. She was renowned for being outstanding in everything she tackled but, crucially, in areas that extended beyond the narrow confines of the discipline itself. Above all, she mastered the soft skills whose importance is increasingly recognized today. In that sense, she was ahead of her time.

\section{Disclosures}

The authors report no conflict of interest concerning the materi- als or methods used in this study or the findings specified in this paper.

\section{Correspondence}

Rossana Romani: romanirossana16@gmail.com.

\section{María Cristina García-Sancho \\ Laura L. Fernández, Sarita Aristizabal, and Elizabeth E. Ginalis, MD}

The first Latin American woman in neurosurgery was Dr. María Cristina García-Sancho y Álvarez-Tostado de Penichet (1919-2013). ${ }^{10,11}$ At the time she began her medical career in the 1940s, the specialty was largely dominated by men. She attended medical school at the National Autonomous University of Mexico, where the overwhelming majority of students were men. ${ }^{11}$ Following medical school, she continued her training at multiple hospitals in Latin America, North America, and Europe, giving her a diversity of experiences. ${ }^{11,12}$ Ultimately, she came back to Mexico and assumed the role of head of Neurosurgery Services at the National Institute of Oncology. ${ }^{11}$

Dr. García-Sancho (Fig. 2) was best recognized for her work on chronic, intractable pain and, particularly, its

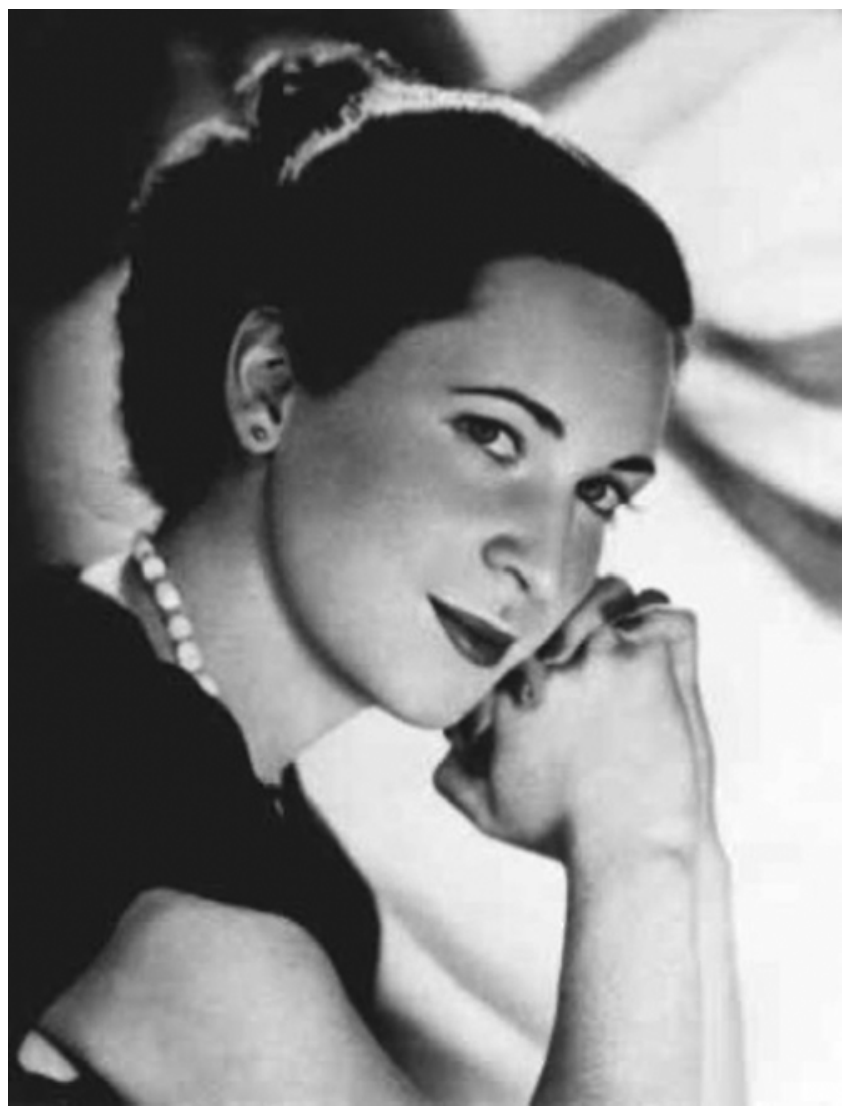

FIG. 2. Photograph of Dr. María Cristina García-Sancho. From Castañeda G, Rodríguez de Romo A. María Cristina García-Sancho y Álvarez-Tostado: first female neurosurgeon in Latin America. Salud Ment. 2010;33(2):111-121. CC BY-NC 3.0 (https://creativecommons.org/ licenses/by-nc/3.0/). Copyright Ana Cecilia Rodríguez de Romo. Published with permission. 
management with the cordotomy technique. ${ }^{11,12}$ She authored multiple publications as well as a book titled Dolor, diagnóstico y tratamiento (pain, diagnosis, and treatment) on this topic. Throughout her career, she treated hundreds of patients with this surgery and ultimately developed her own variation of the cordotomy, in which it was performed in one step rather than two, as traditionally done..11,12 This innovative technique was regarded as a substantial advancement in the field throughout Mexico and Latin America. ${ }^{11}$

\section{Disclosures}

The authors report no conflict of interest concerning the materials or methods used in this study or the findings specified in this paper.

\section{Correspondence}

Elizabeth E. Ginalis: elizabeth.ginalis@rutgers.edu.

\section{Thanjavur S. Kanaka}

\section{Ahmad Ozair, Vivek Bhat, Arjumand Faruqi, Ankur Bajaj, MCh, and Abhinav Arun Sonkar, MS, FRCS}

Asia's first and the world's fifth fully qualified female neurosurgeon, Dr. Thanjavur Santhanakrishna Kanaka, was born in 1932 at Madras in India (Fig. 3). Widely known as T. S. Kanaka, she was among the few women to enter medical school in the late 1940s. At Madras Medical College, her interest in neurosurgery was developed by Dr. B. Ramamurthi (1922-2003), head of one of the earliest departments of neurosurgery in India. ${ }^{13,14}$

Completing MBBS studies in 1954, Kanaka spent several years trying to qualify for the general surgery residency entrance examination due to the significant bias of examiners against women. ${ }^{14}$ After she was selected, her chief resident would deny her autonomy in managing cases and operative training. Passing out of residency was even more difficult, given the discrimination against females in the residency exit examination. She passed on her sixth attempt, earning the degree of MS (surgery).

The road ahead was easier, as Kanaka then found a willing mentor in Dr. B. Ramamurthi for MS (neurosurgery).${ }^{14} \mathrm{He}$ devotedly taught Kanaka, gave her autonomy, and helped her flourish. Completing neurosurgical training under him in 1968, she then pursued a PhD in stereotactic neurosurgery. She finished her thesis on the surgical management of cerebral palsy in 1972 at the age of 40 years. ${ }^{2}$ The same year saw the start of the Madras Institute of Neurology (MIN), a center of excellence in neurosciences. ${ }^{1}$ Joining MIN as a consultant, Kanaka found the atmosphere to excel both inside and outside of the operating room, working with progressive-minded and academically productive colleagues. Together, they carried out the first surgeries in India for epilepsy, behavioral and psychiatric disorders, tremors, and spasticity, leading to Madras becoming the birthplace and the leader of functional neurosurgery in India. ${ }^{15-17}$

Early in her life, she had decided to not marry, choosing to devote her time solely to patient care, research, and training. ${ }^{16}$ Postresidency, she was well renowned to almost live in the hospital throughout her career. ${ }^{14}$ She refused to join private practice despite several lucrative offers, even from overseas, and continued services at MIN at a meager salary.

Her pioneering research works described management of cerebral palsy, combined ablative lesions for spasticity, hypothalamotomy for juvenile aggression, bilateral cingulumotomy for drug addiction, limbic lesioning for epilepsy, electrophysiological studies during sedative neurosurgery, cerebellar stimulation for spasticity, and more. ${ }^{13,14,17}$ She was the first in India to perform chronic

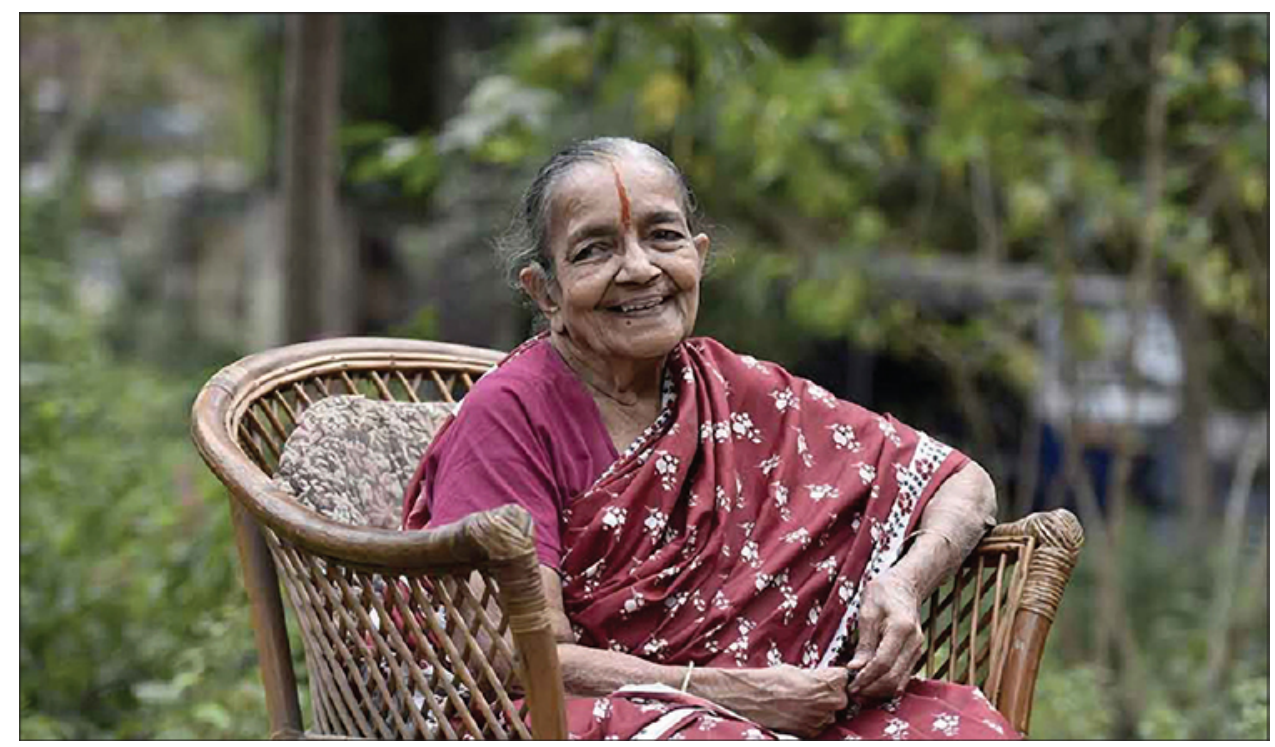

FIG. 3. Photograph of Dr. T. S. Kanaka taken in the last few days of her life. Reproduced from Ganapathy K. In memoriam: Thanjavur Santhanakrishna Kanaka (31st March 1932 - 14th Nov 2018). Neurol India. 2018;66(6):1872-1876. CC BY-NC-SA 4.0 license (https://creativecommons.org/licenses/by-nc-sa/4.0/). 
electrode implantation for deep brain stimulation (DBS) and worked on developing low-cost DBS systems for decades. ${ }^{16,17}$ She earned several awards and guest lecture invitations from numerous organizations worldwide, including the Walter Dandy Neurosurgical Society. ${ }^{14}$ Under her guidance, the Asian Women's Neurosurgical Association and the WINSI (Women in Neurosurgery in India) forum were established..$^{14}$

Kanaka retired from MIN in 1990. She used her life savings to establish the Sri Santhanakrishna Padmavathy Health Care and Research Foundation, a center where she provided free consultation for common medical problems and free laboratory investigations for the elderly and the poor. ${ }^{14,16}$ She passed away at the age of 86 in 2018, having continued her nonprofit work until her last days. ${ }^{14}$ It is the selfless dedication of T. S. Kanaka toward her patients and her trainees that made her legacy everlasting.

\section{Disclosures}

The authors report no conflict of interest concerning the materials or methods used in this study or the findings specified in this paper.

\section{Correspondence}

Vivek Bhat: email.vivekbhat@gmail.com.

\section{Carole A. Miller, MD}

Daniel S. Ikeda, MD, E. Antonio Chiocca, MD, PhD,

Russell R. Lonser, MD, Tracy E. Sutton,

John M. McGregor, MD, Gary L. Rea, MD, PhD,

Victoria A. Schunemann, MD, Laura B. Ngwenya, MD, PhD,

Evan S. Marlin, MD, Paul N. Porensky, MD,

Ammar Shaikhouni, MD, PhD, Kristin Huntoon, DO, PhD,

David Dornbos III, MD, Andrew B. Shaw, MD, and

Ciarán J. Powers, MD, PhD

The peak of the healer's art is in bringing both science and empathy to bear on disease. This is what being a physician should mean.

\section{- Carole A. Miller, MD (1994) $)^{18}$}

Carole A. Miller was born in Kalamazoo, Michigan, on May 7, 1939. She obtained her undergraduate and medical degrees at The Ohio State University, where she graduated with honors in 1966.19,20 After spending her intern year at the Hospital of the University of Pennsylvania, she returned to The Ohio State University Medical Center (OSUMC) for residency training in neurological surgery. After graduation from residency, she completed a fellowship in neurophysiology at Yale University. ${ }^{20}$ When asked about breaking through the glass ceiling of neurosurgical training, she stated, "It never occurred to me I couldn't be a neurosurgeon.... If there was male chauvinism, I chose to ignore it." 20,21

With her first job as staff at the University of Michigan, she would become the first woman on surgical faculty and only the fourth female ABNS diplomate.22 In 1975, Dr. Miller returned to OSUMC as an assistant professor and embarked on what would become a long, distinguished career. In 1990, she was honored as professor. After the pass- ing of the division chief, Dr. William Hunt, she assumed the role of interim chief from 1989 to 1991. Again, from 2003 to 2004, she served as interim chair of the newly established Department of Neurosurgery. ${ }^{19}$ As residency director with chairs E. Antonio "Nino" Chiocca, MD, PhD, and Russell R. Lonser, MD, she would lead the OSUMC program from near loss of accreditation to the model of training it is today.

Dr. Miller led the way for female inclusion and leadership in organized neurosurgery at institutional, state, and national levels. She became the first woman to be invited as a guest examiner for the ABNS oral examination (1987); elected to our oldest organization, The Society of Neurological Surgeons (1988); and elected the president of the Ohio State Neurological Society (1989); as well as to take a leadership role at a national level, as chair of the Joint AANS/CNS Joint Section on Disorders of the Spine and Peripheral Nerves (1991). ${ }^{19}$ With more than 60 peerreviewed publications, Dr. Miller was a prolific contributor to the body of neurosurgical research. She frequently collaborated with her long-time colleague and eventual husband, another leader in neurosurgery, Dr. Hunt. Finally, she became the first female leader of a national organization as president of the Neurosurgical Society of America (Fig. 4).

After a courageous battle with cancer, Dr. Miller passed away peacefully on October 28, 2015, on the OSUMC campus. The Carole A. Miller, MD, Annual Lecture at OSUMC was subsequently established, and three contemporary neurosurgical pioneers, Shelly D. Timmons, MD, PhD (2017), Julie G. Pilitsis, MD, PhD (2018), and Amy B. Heimberger, MD (2019), have honored her memory as lecturers. One of Dr. Miller's oldest colleagues, Dr. John McGregor, stated that when she came to OSUMC,

This program became different. We have a camaraderie, a shared sense of purpose, a collegial commitment to excellence, the IT factor that sets this program apart. She infused IT into neurosurgery at Ohio State University from the beginning. She planted those seeds.

\section{Disclaimer}

The views expressed are solely those of the authors and do not reflect the official policy or position of the US Navy, the Department of Defense, or the US Government.

\section{Disclosures}

The authors report no conflict of interest concerning the materials or methods used in this study or the findings specified in this paper.

\section{Correspondence}

Daniel S. Ikeda: daniel.s.ikeda@gmail.com.

\section{Alexa Canady \\ Jacob M. Gluski, BSc, Lauren G. Culver, BSc, Alyssa M. Goodwin, BSc, Steven Ham, DO, and Neena I. Marupudi, MD, MS}

Alexa Canady was born on November 7, 1950, in Lansing, Michigan, to well-educated parents who fostered her intellectual curiosity. Alexa often felt conspicuous of her 

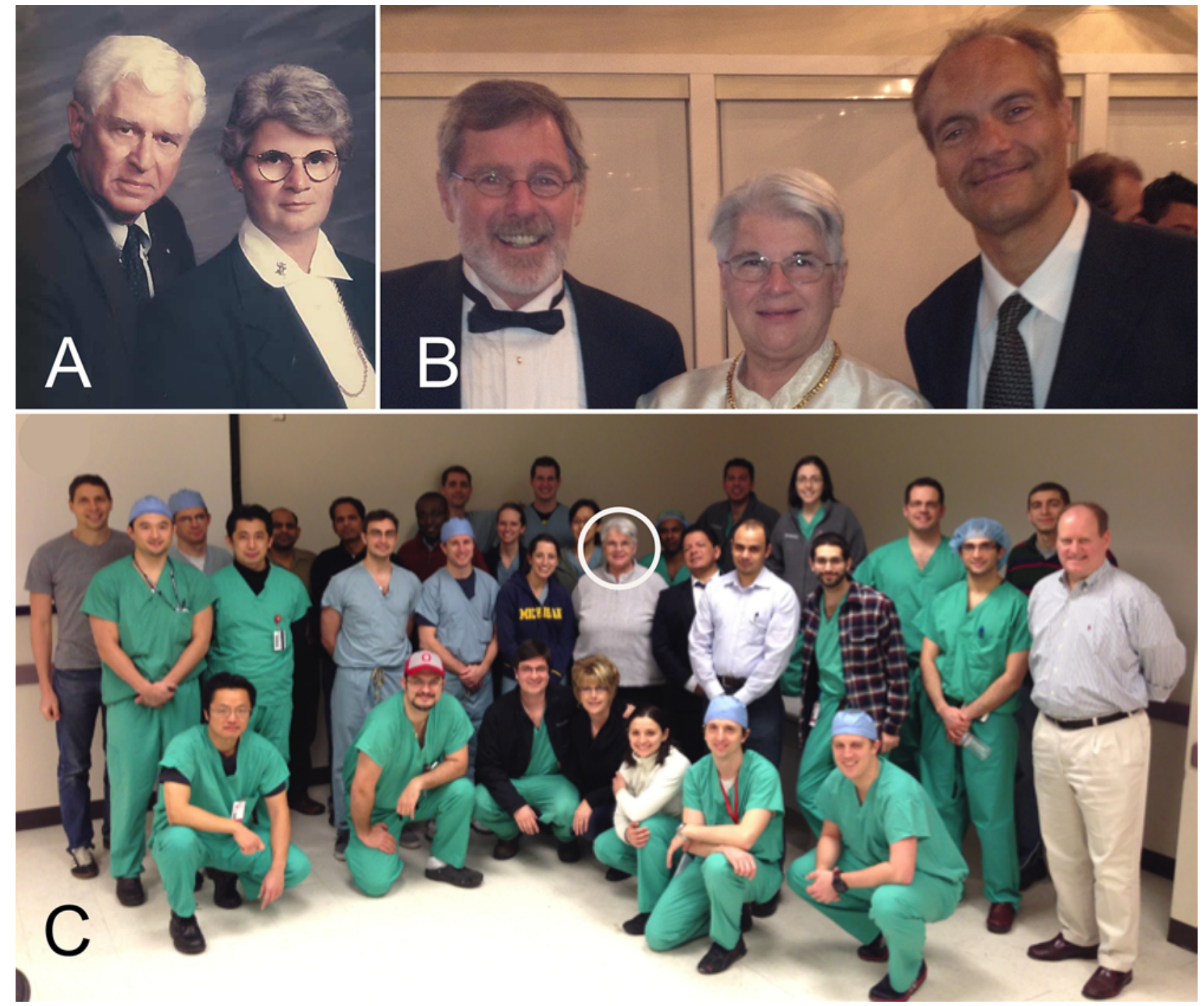

FIG. 4. Photographs of Dr. Miller with colleagues and residents. A: Dr. Miller with her long-time colleague and eventual husband, Dr. William E. Hunt. B: Dr. Miller standing center between Dr. John McGregor (left) and former OSUMC neurosurgery chair (2004-2012) Dr. E. Antonio "Nino" Chiocca (right). C: Dr. Miller (white circle) standing among several OSUMC and University of Michigan residents and faculty during an annual skull base course in 2013. Copyright Daniel S. Ikeda. Published with permission.

race while attending her rural elementary school. This was made worse by the overt racism of her second grade teacher, who surreptitiously switched Alexa's excellent quizzes with those of an average White classmate. ${ }^{23}$ This was only discovered by her parents when Alexa volunteered for a local college's psychology testing class and demonstrated impressive intelligence (Fig. 5).

Alexa's journey into medicine began the summer following her junior year at the University of Michigan, when her brother mentioned a fellowship for minorities in health sciences. It was through this fellowship that she grew to see medicine as a career. While attending the University of Michigan Medical School, neuroanatomy captured Alexa's interest, and this curiosity grew into a passion for neurosurgery.

Dr. Canady went on to graduate cum laude, completed a surgical internship at Yale followed by residency at the
University of Minnesota, and finished her training with a fellowship in pediatric neurosurgery at the Children's Hospital of Philadelphia mentored by Luis Schut, whom Dr. Canady would later describe as her "mentor in life.".

In 1984, Dr. Canady became the first board-certified African American female neurosurgeon. Shortly thereafter, she became chief of neurosurgery at Children's Hospital of Michigan, where she would grow the program into a national contender. Her department was academically fruitful, resulting in Dr. Canady publishing 52 papers and giving more than 130 scientific presentations. ${ }^{25}$ Wayne State University appointed Dr. Canady to a full professorship in neurosurgery; she is one of the few women to achieve this post. Even today, only $5.84 \%$ of neurosurgery professorships are held by women. ${ }^{26}$ For these and many other achievements, Dr. Canady was inducted into The Society of Neurological Surgeons in 1995. 


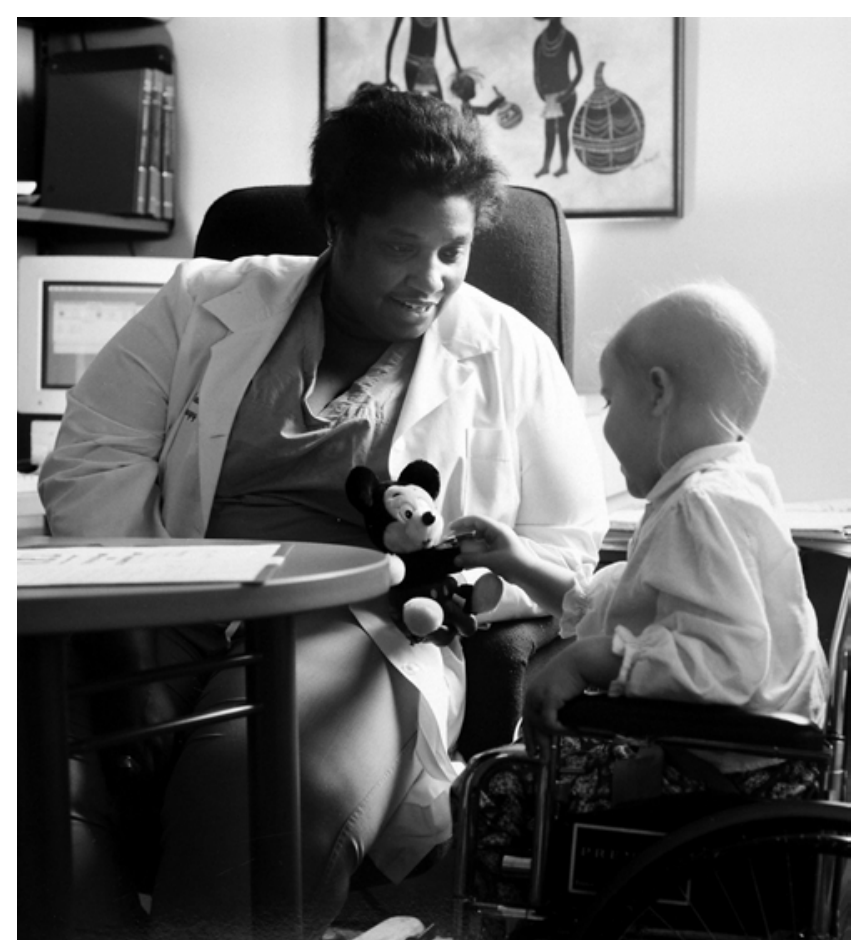

FIG. 5. Photograph of Dr. Alexa Canady. Copyright Children's Hospital of Michigan; used with permission.

Patients came first in Dr. Canady's department. In pediatrics, this meant keeping abreast of the latest video games and assuaging the fears of children before addressing the grown-ups. Dr. Canady also spent many hours at her patients' bedsides, often rounding twice a day. Every member of her team was encouraged to speak up if they had ideas about a patient's care, no matter how junior their position. Included in her conception of the team were the housekeeping staff: Dr. Canady astutely observed that, while a hospital can function without neurosurgeons, it would quickly shutter without housekeepers. ${ }^{27}$

Along the way, she mentored many neurosurgeons, male and female alike, notably, Drs. Julie Pilitsis, Steven Ham, and Sandeep Sood. When asked about Dr. Canady, all remarked on her exceptional ability to encourage, inspire, and deliver constructive criticism. Dr. Pilitsis said, "One of Dr. Canady's roles was to help ascertain the strengths and weaknesses of residents. She was definitely the toughest trainer, frankly because I think she cared the most about our education and neurosurgery." In the spirit of Dr. Canady's teaching, Dr. Pilitsis tries to fulfill the same role for her own trainees.

Dr. Canady fully retired from surgery in 2012 and now lives in Pensacola, Florida, with her husband, George Davis.

\section{Disclosures}

The authors report no conflict of interest concerning the materials or methods used in this study or the findings specified in this paper.

\section{Correspondence}

Neena I. Marupudi: neena.marupudi@gmail.com.

\section{Bhagavatula Indira Devi \\ Dhananjaya I. Bhat, MCh(Neurosurgery)}

Dr. Devi, professor and former head of the Department of Neurosurgery, National Institute of Mental Health and Neurosciences (NIMHANS), Bangalore, India, graduated from Andhra Medical College, Visakhapatnam. In 1988, she completed her general surgery and neurosurgery training from the Postgraduate Institute of Medical Education and Research (PGIMER), in Chandigarh. She joined NIMHANS in 1993 as assistant professor and has slowly and steadily worked her way forward, reaching the higher echelons of academics at NIMHANS, culminating in professorship (2007).

Foraying into a "macho" neurosurgery specialty was no mean task, and it raised many eyebrows. Can a girl run the gauntlet, endure the hardships and become a successful practicing neurosurgeon? This was the doubt in many minds. But with sheer grit, tenacity, and perseverance, she proved her detractors wrong.

A surgeon par excellence, her chief clinical interests include traumatic brain injury, neuro-oncology, vascular, craniovertebral junction disorders, and peripheral nerve surgery. She developed the peripheral nerve subspeciality at NIMHANS. Her understanding and management of peripheral nerve and plexus injuries have earned accolades in national and international arenas. Cortical plasticity in peripheral nerve injuries is one of her areas of keen interest. ${ }^{28,29}$

Her research interests are highly focused on functional and connectivity MRI in traumatic brain injury and peripheral nerve injury. She has been able to demonstrate changes in resting networks in the brain that may shed light into the pathophysiology of brain injury. ${ }^{28,29}$ In the animal laboratory, her research focuses on regeneration after peripheral nerve injuries in rats and developing new coaptation techniques with sutures, glue, different grafts, amniotic membranes, and stem cells. She has also performed various studies on forebrain ischemia models..$^{30}$

She is an erudite scholar and teacher par excellence, has authored more than 280 peer-reviewed articles and many book chapters, and is frequently invited to speak nationally and internationally. More than 120 residents have been trained under her. She is compassionate and sensitive to her patients, and she can go a long way in helping them logistically and financially.

In 2019, she assumed the position of dean of clinical neurosciences. Within the scope of her work notably lies the onus of conducting all neuroscience entry and exit examinations, developing structured syllabi, and overseeing ethical aspects of all research in the institute and smooth functioning of all departments.

Her other accomplishments include being presidentelect of the Indian Society of Peripheral Nerve Surgery (2020-2021), an editorial board member of Neurology India, a coprincipal investigator of the RESCUE ASDH trial (National Institutes of Health Oxford-Cambridge group), a cochair of the World Federation of Neurosurgical Societies (WFNS) Committee on Peripheral Nerve Surgeries, a member of the newly constituted Global Neurosurgery Committee of the WFNS, and a member of the Neurotrau- 
matology Committee of the WFNS. Pioneering work in decompressive craniotomy for developing countries has been done by her with the reintroduction of hinge craniotomies.

Dr. Devi is an avid reader, and her genres are varied, ranging from academic books to spirituality, philosophy, science, and fiction.

Her penchant for photography and gifting books and memorabilia, her infallible memory, and her amicable personality have won her a large number of friends and wellwishers.

\section{Disclosures}

The author reports no conflict of interest.

\section{Correspondence}

Dhananjaya I. Bhat: dhananjayaibhat@gmail.com.

\section{Spine Leaders in Neurosurgery}

Katherine M. Berry, MD, Eva M. Wu, MD, and

Michael Y. Wang, MD

\section{Frances Conley, MD}

Dr. Conley was a pioneering force in the recognition of discrimination against women pursuing careers in the medical field and even authored a book titled Walking Out on the Boys, a personal account of her departure and return to academic neurosurgery after achieving unprecedented success as the first tenured female professor of neurosurgery in the United States, at Stanford University (Fig. 6).

She completed neurosurgery residency at Stanford University and was the first female resident in surgery at Stanford. ${ }^{31}$ She also earned a Master of Science in Management. ${ }^{32}$ She displayed an elegance and remarkable technical ability early in her residency. This, and her uniqueness as a female in a male-dominated specialty, catapulted her to national renown. Her research interests were numerous, but in the field of spine surgery, she was a pioneer of spinal stabilization, reconstruction, and instrumentation. She published numerous papers and was awarded several grants for her research in spine. ${ }^{32}$

\section{Marjorie Wang, MD}

Dr. Wang (Fig. 7) has excelled as a clinician and surgeon, an educator of residents and fellows, a pioneering researcher, and an advocate for neurosurgery and neurosurgeons. She completed neurosurgery residency at the University of Colorado, followed by a complex spine fellowship at the Medical College of Wisconsin (MCW). Today, she serves as the director of that same fellowship. Her passion for improving access to quality healthcare and improving outcomes in neurosurgery motivated her to pursue a master's degree in public health. In 2011, she was named the Robert Wood Johnson Clinical Scholar at the University of Washington. ${ }^{33}$

In addition to her directorship of the Complex Spine Fellowship Program at MCW, Dr. Wang is a professor of neurosurgery, serves as vice chair of Clinical Operations and Quality at MCW, and is the chief of the Community Division of Neurosurgery. ${ }^{34}$ Her commitment to education,

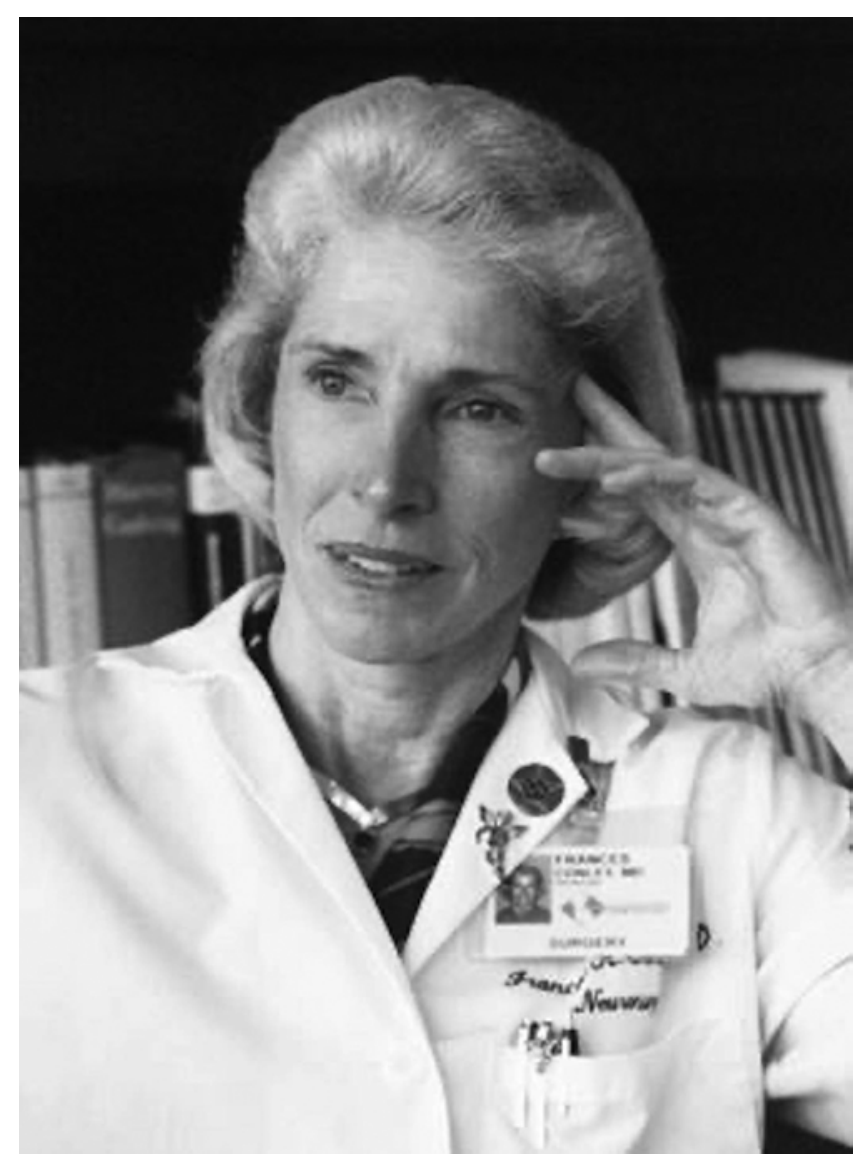

FIG. 6. Photograph of Dr. Frances Conley. Copyright Women in Neurosurgery. Published with permission.

advancement of the field of neurosurgery, and contribution to organized neurosurgery cannot be understated. Dr. Wang's research focuses on patient outcomes after spine surgery, quality improvement, and systemic health services. She has served as the chair-elect and secretary of the AANS/CNS Joint Section on Disorders of the Spine and Peripheral Nerves. Dr. Wang was elected to the editorial board of the Journal of Neurosurgery: Spine in 2019 and serves as a spine section editor for World Neurosurgery. She is a director of the ABNS and was one of $61 \mathrm{se-}$ nior female faculty members selected to participate in the 2019-2020 Hedwig van Ameringen Executive Leadership in Academic Medicine Program for Women. ${ }^{35}$

\section{Shelly D. Timmons, MD, PhD}

As the first female neurosurgeon to serve as president of the AANS, Dr. Timmons is certainly breaking barriers for women in neurosurgery (Fig. 8). ${ }^{21}$ In addition, she is the chair of the Department of Neurosurgery at Indiana University. Her research focus is primarily in trauma and creating evidence-based systems for the diagnosis and treatment of neurosurgical disorders, including disorders of the spine. She has published numerous articles on the diagnosis and management of blunt cerebrovascular injury, which often occurs comorbidly with cervical spine injury. ${ }^{36}$ In addition, she has published evidence-based guidelines on 


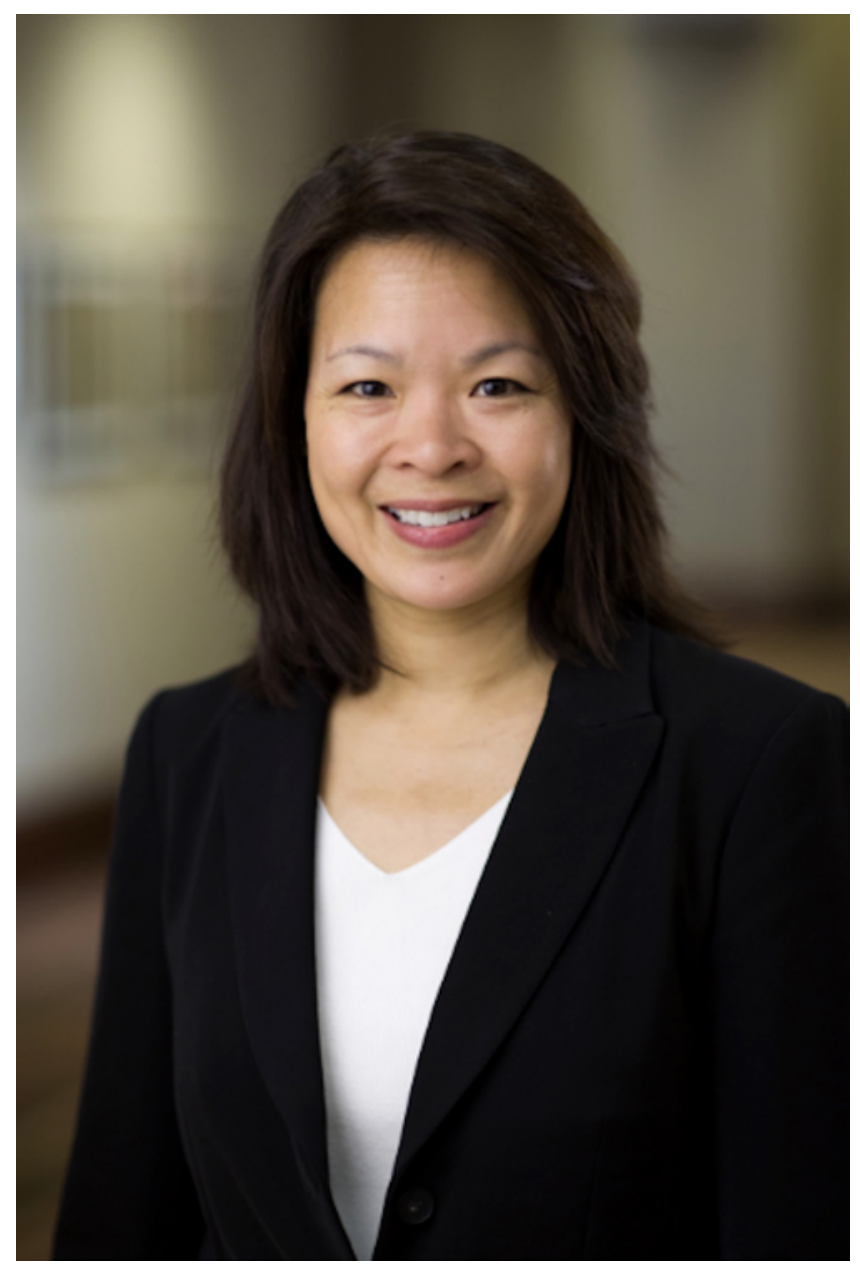

FIG. 7. Photograph of Dr. Marjorie Wang. Copyright American Board of Neurological Surgery. Published with permission.

the diagnosis and treatment of cervical radiculopathy as well as degenerative lumbar spondylolisthesis. She is a frequent collaborator for establishing consensus guidelines in neurotrauma, with ongoing contributions to consensus and evidence-based practices for spine surgery. ${ }^{37}$

\section{Deborah Benzil, MD}

Dr. Deborah Benzil is one of the founding members of the Women in Neurosurgery (WINS) organization. She served as the first president of the organization and was instrumental to its inclusion as a subsection of the AANS (Fig. 9). As legend has it, in 1989, a group of 8 women met at a national neurosurgery meeting in Atlanta, all noting that this was the first time they had seen other women at a professional meeting. Their conversations that day led to the creation of the WINS organization. She has been instrumental in the successful recruitment and retention of women into the neurosurgical workforce through mentorship and advocacy. She has published numerous papers examining gender differences in neurosurgery, from the medical student to the attending level..$^{38-41}$ She has been instrumental in increasing the percentage of female neurosurgeons so that one day we are no longer "less than

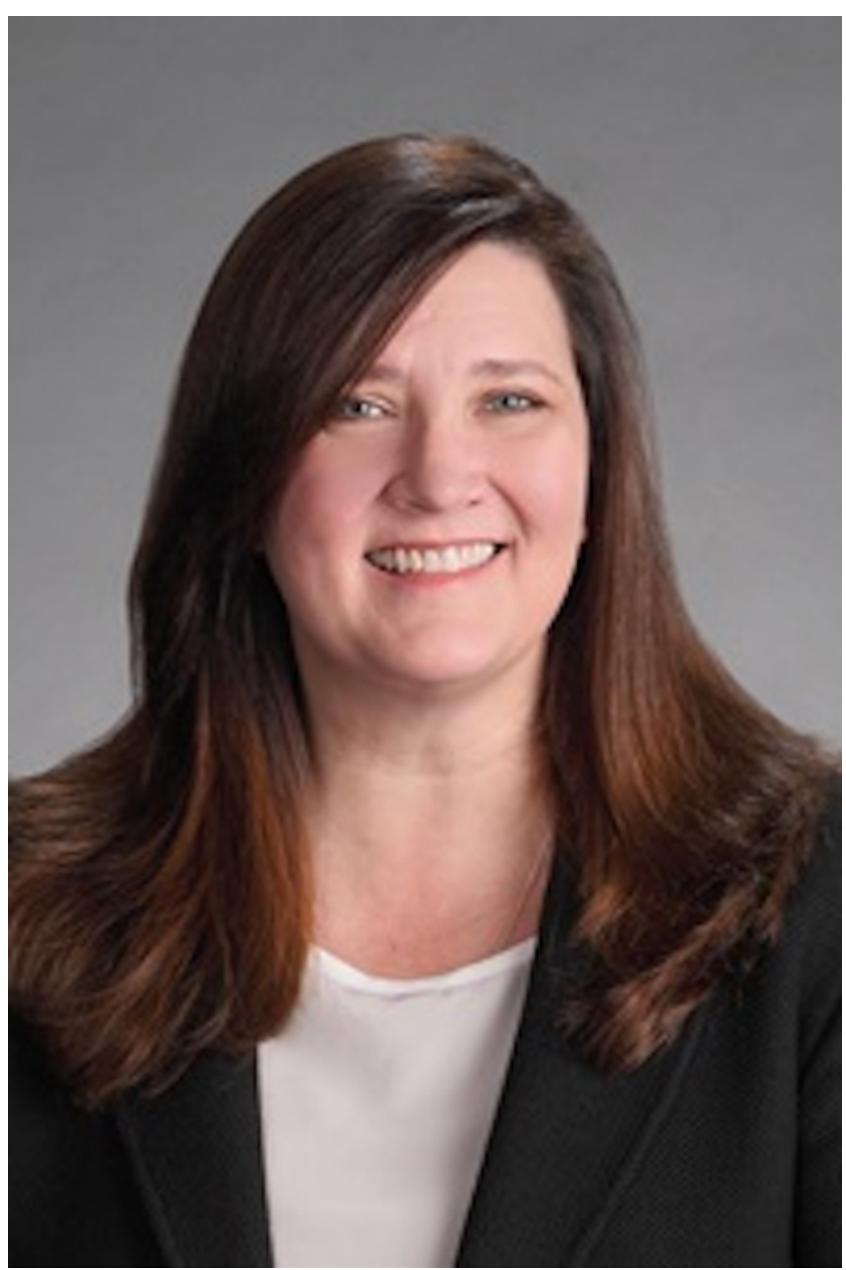

FIG. 8. AANS official portrait of Dr. Shelly Timmons.

a minority," as Robert Spetzler famously stated in his outstanding paper on the history of women in neurosurgery. 42

She is a leader in spine surgery, spinal cord injury, and the socioeconomics of spine surgery. She has performed research on spinal cord injury among US Army special forces. She has also been a leader in establishing guidelines for safe stereotactic radiosurgery of spinal tumors. ${ }^{43}$

\section{Erica Bisson, MD, MPH}

Dr. Bisson is an associate professor of neurosurgery and the director of the Complex Spine Fellowship at the University of Utah (Fig. 10). She completed neurosurgery residency at the University of Vermont and a complex spine fellowship at University of Utah prior to joining the faculty in 2009. While at the University of Utah, she also received her master's degree in public health.

Her dedication to the advancement of spine surgery extends beyond educating residents and fellows. She serves on the AANS/CNS Joint Section on Disorders of the Spine and Peripheral Nerves. She is the chair of the Outcomes Committee for the Cervical Spine Research Society, and, 


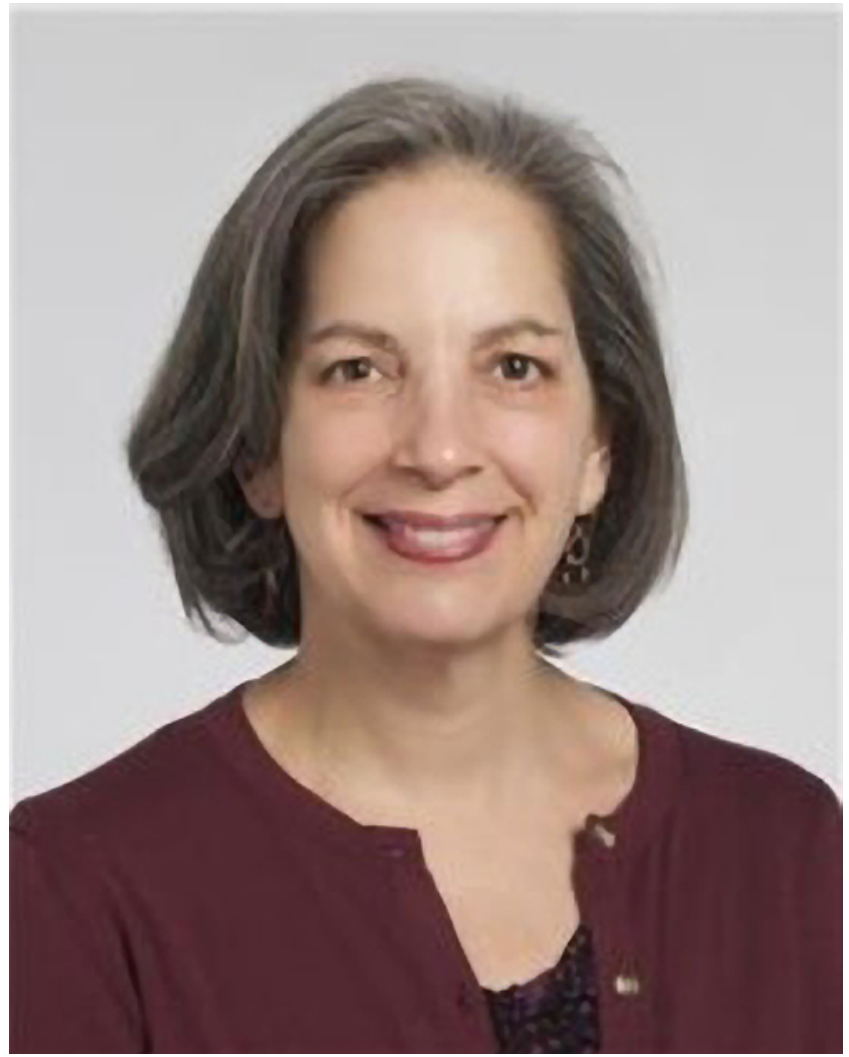

FIG. 9. Photograph of Dr. Deborah Benzil. Copyright Deborah Benzil. Published with permission.

in 2018, she was elected to the editorial board of the Journal of Neurosurgery: Spine. ${ }^{44}$

\section{Arun Ganju, MD}

Dr. Ganju completed residency training at Henry Ford Hospital. She has made it her mission to foster women in medicine through mentorship programs (Fig. 11). Her work with female students at the Illinois Math and Science Academy has resulted in $66 \%$ of the students pursuing a career in medicine. She has worked with more than 50 medical students at Northwestern University School of Medicine who went on to pursue a career in neurosurgery and spine surgery. Of those medical students, $9(18 \%)$ were women..$^{45}$ Dr. Ganju served as president of WINS from 2014 to 2015. ${ }^{46}$

Specializing in spinal column and spinal cord disease, Dr. Ganju continues to advance the field as an associate professor of neurological surgery and orthopedic surgery at Northwestern University. She is a member of the international Spine Oncology Study Group, a multidisciplinary group dedicated to the treatment and understanding of spinal column tumors. Her current research focuses on outcomes of spinal cord disease and basal energy expenditure in patients with lumbar spondylolisthesis. ${ }^{45}$

\section{Eve Tsai, MD}

Dr. Tsai is an outstanding physician-scientist in the world of spinal cord injury, myelopathy, applied radiology, and translational research (Fig. 12). She currently serves

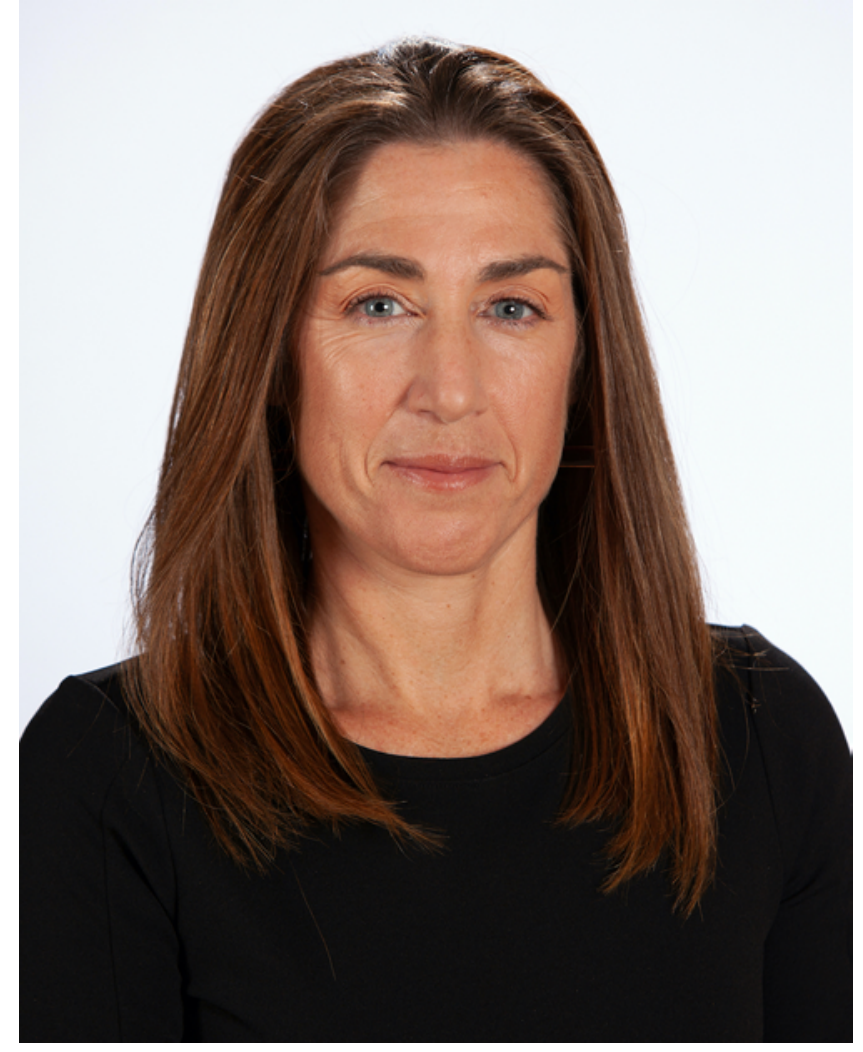

FIG. 10. Photograph of Dr. Erica Bisson. Copyright University of Utah Neurosurgery. Published with permission.

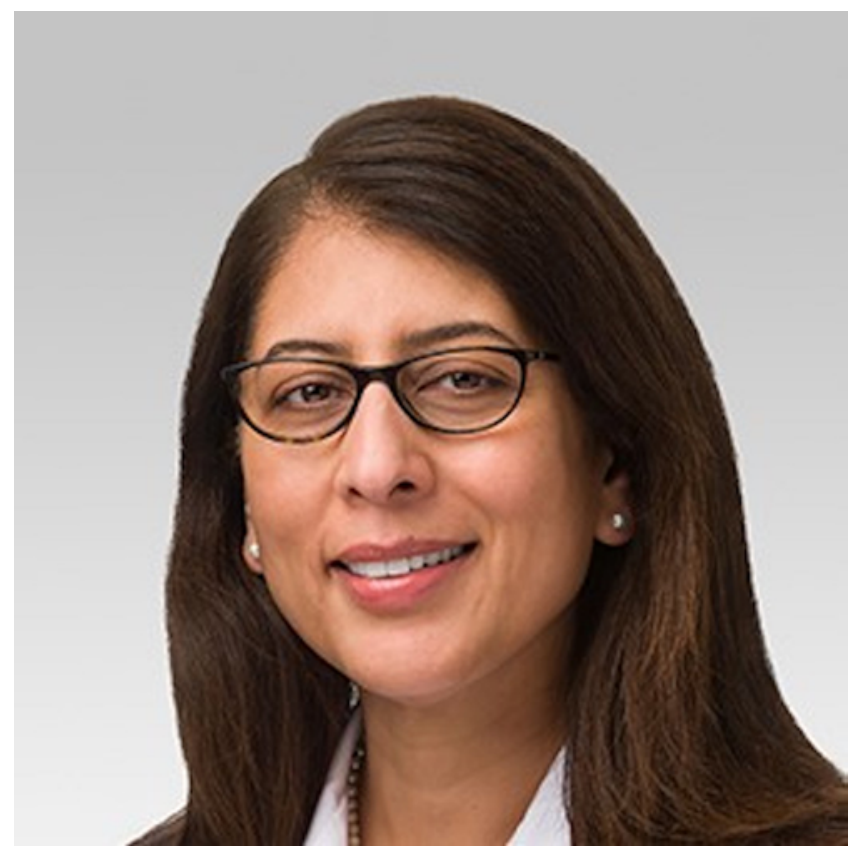

FIG. 11. Photograph of Dr. Aruna Ganju. Copyright Aruna Ganju. Published with permission. 


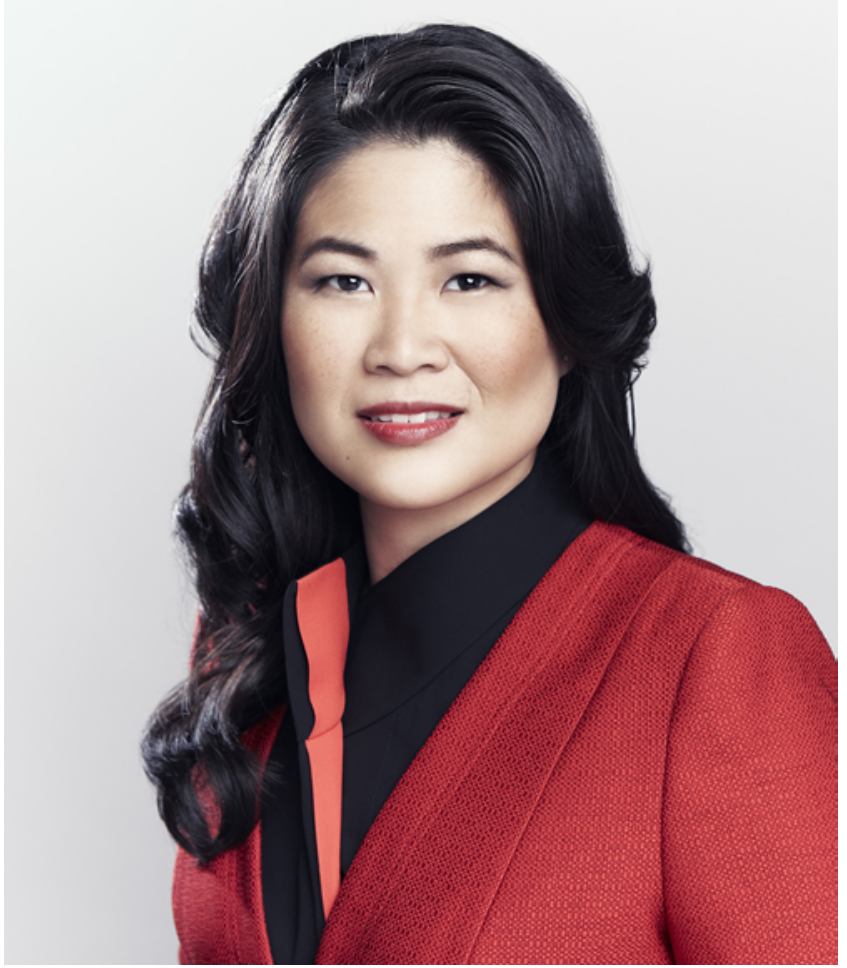

FIG. 12. Photograph of Dr. Eve Tsai. Copyright 2011 Kourosh Keshiri. Used with permission.

as an associate scientist in the neuroscience program at the Ottawa Hospital Research Institute and as an assistant professor for the Department of Surgery in the Division of Neurosurgery at the University of Ottawa, where she holds the Suruchi Bhargava Chair in Spinal Cord and Brain Regeneration Research.

Dr. Tsai's achievements are well known to her peers and colleagues. She served as the president of WINS from 2012 to 2013. She is the recipient of numerous awards, including Canada's Top 40 Under 40 Award and Top 25 Women of Influence by Women of Influence Magazine.

Dr. Tsai completed neurosurgery residency at the University of Toronto, obtained a PhD in spinal cord repair, and completed a spine fellowship at the Cleveland Clinic. Her research focuses on spinal cord injury repair strategies, axonal regeneration, clinical outcomes after spine surgery, and MRI of spinal cord tracts in humans and animals using diffusion tensor imaging and other experimental modalities. ${ }^{47}$

\section{Ann Parr, MD}

Dr. Parr is an associate professor of neurosurgery at the University of Minnesota and is the director of the spinal neurosurgery program (Fig. 13). ${ }^{46}$ In addition, she is the principal investigator in the Parr Laboratory and at the University of Minnesota's Stem Cell Institute. Her dedication to neuroscience extends beyond medical education, as she is also a faculty member in the Graduate Program in Neuroscience and Spinal Cord Injury. She is both a fellow

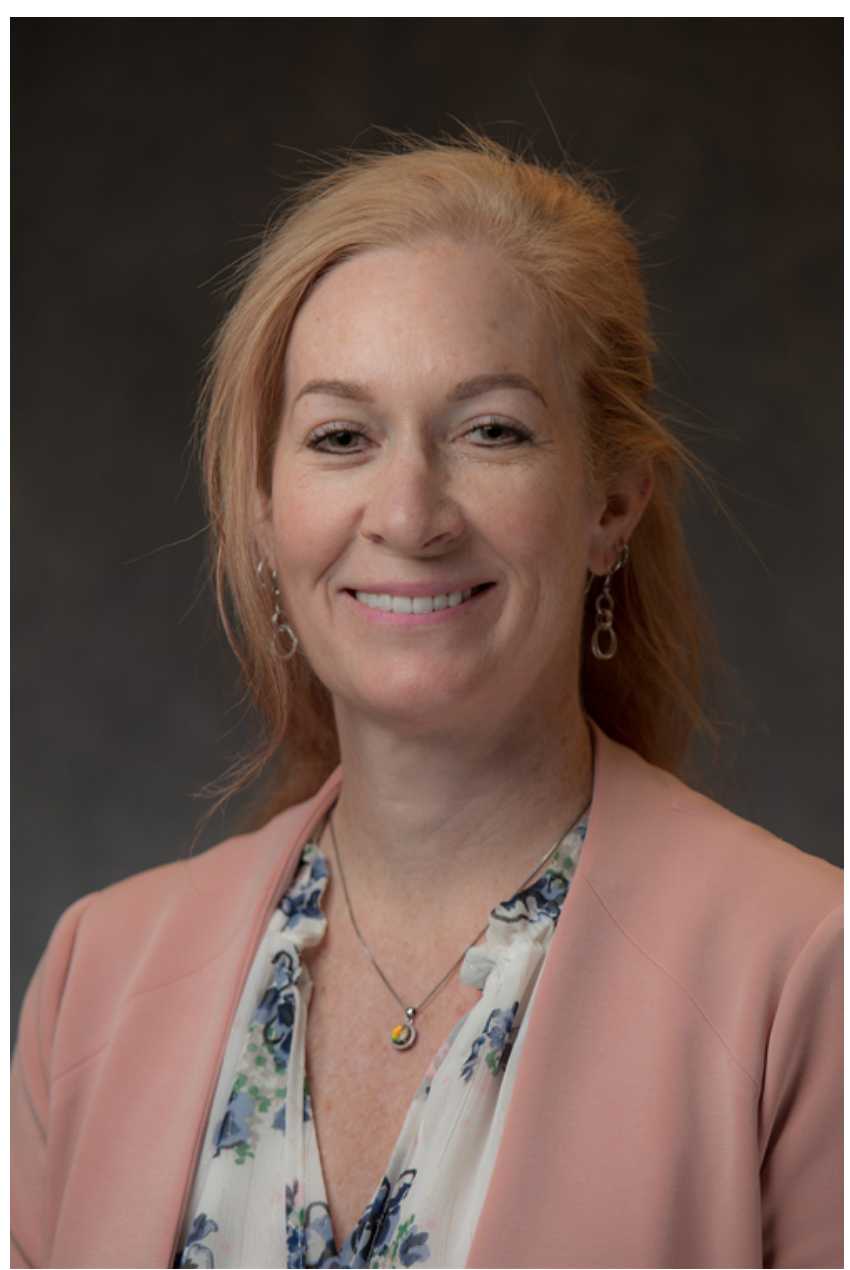

FIG. 13. Photograph of Dr. Ann Parr. Copyright Ann Parr. Published with permission.

of the AANS and a fellow of the ABNS. She served as president of WINS from 2017 to $2018 .^{46}$

Dr. Parr is the recipient of numerous awards for her research, including an NIH K award, and has several active, ongoing research projects in translational stem cell research for spinal cord injury. Her disparate sources of funding for her research serve as a testament to her productivity, innovation, and contribution to the field of spinal cord injury research. Her work is funded by organizations such as the Minnesota Spinal Cord Injury and Traumatic Brain Injury Research Grant Program, the Morton Cure Paralysis Foundation, the University of Minnesota Foundation, and Vertex Pharmaceuticals. She is also site leader for several business and industry clinical trials. ${ }^{48}$

\section{Disclosures}

Dr. Wang: consultant for DePuy Synthes, Medtronic, Stryker, and Spineology; patent holder with DePuy Synthes; and direct stock ownership in ISD, Medical Device Partners, and Kinesiometrics.

\section{Correspondence}

Katherine M. Berry: katherine.berry@jhsmiami.org. 


\section{References}

1. Dr. Dorothy K. Nash, neurosurgeon, dies. New York Times. March 6, 1976. Accessed January 18, 2021. https://www. nytimes.com/1976/03/06/archives/dr-dorothy-k-nashneurosurgeon-dies.html

2. Stookey B, Klenke D. A study of the spinal fluid pressure in the differential diagnosis of diseases of the spinal cord. Arch Neurol Psychiatry. 1928;20(1):84-109.

3. Wortis SB, Klenke D. Experimental convulsions following lesions of the tuber cinereum. Am J Psychiatry. 1933;89(5): 1039-1047.

4. McLaughlin MR, Subach BR, Lunsford LD, Jannetta PJ. The origin and evolution of the University of Pittsburgh Department of Neurological Surgery. Neurosurgery. 1998; 42(4):893-898.

5. Dorothy K. Nash, 77, pioneer neurosurgeon. Obituary. Pittsburgh Post-Gazette, Sun-Telegraph (1960-1978). March 6, 1976:5.

6. Cerebral palsy campaign. Pittsburgh Post-Gazette (19272003). August 29, 1953:5.

7. Mental health talks open. Pittsburgh Post-Gazette (19272003). February 15, 1957:17.

8. Dr. Nash receives award. Pittsburgh Post-Gazette (19272003). June 19, 1957:13.

9. Gilkes CE. An account of the life and achievements of Miss Diana Beck, neurosurgeon (1902-1956). Neurosurgery. 2008; 62(3):738-742

10. Mejía-Pérez SI, Cervera-Martínez C, Sánchez-Correa TE, Corona-Vázquezo $\mathrm{T}$. The woman in neurosurgery at the National Institute of Neurology and Neurosurgery. Article in Spanish. Gac Med Mex. 2017;153(2):279-282.

11. López GC, de Romo ACR. María Cristina García-Sancho y Álvarez-Tostado: first female neurosurgeon in Latin America. Salud Ment. 2010;33(2):111-121.

12. López GC, de Romo ACR. El Instituto de Neurocirugía e Investigaciones Cerebrales de Santiago de Chile y la primera neurocirujana en Latinoamérica. Rev Chile Neurocir. 2009; 32(2):44-49.

13. Ramesh VG, Bhanu K, Jothi R. The Madras Institute of Neurology, Madras Medical College, Chennai. Neurol India. 2015;63(6):940-946.

14. Ganapathy K. In memoriam: Thanjavur Santhanakrishna Kanaka (31st March 1932 - 14th Nov 2018). Neurol India. 2018;66(6):1872-1876.

15. Kanaka TS. Back to the future: glimpses into the past. Neurol India. 2016;64(2):206-207.

16. Satyarthee GD, Jagdevan A. T. S. Kanaka: first Asian woman neurosurgeon, who pioneered stereotactic, functional and cerebral electrode implant surgery and developed separate neurosurgical speciality in India early 1970. Asian J Neurosurg. 2019;14(3):1050.

17. Ramamurthi B. Stereotactic surgery in India: the past, present and the future. Neurol India. 2000;48(1):1-7.

18. Miller CA. What's a woman doing in a place like this? Surg Neurol. 1994:42(2):171-176.

19. Women in Neurosurgery. Carole Ann Miller, MD. Accessed January 18, 2021. http://www.neurosurgerywins.org/doctor/ dr-carole-miller

20. National Library of Medicine. Meet Local Legend: Carole Miller, M.D. Archived May 8, 2019. Accessed January 18, 2021. https://wayback.archive-it.org/org350/20190508153456/https://www.nlm.nih.gov/exhibition/ locallegends/Biographies/Miller_Carole.html

21. Corley J, Kim E, Philips CA, et al. One hundred years of neurosurgery: contributions of American women. $J$ Neurosurg. 2021;134(2):337-342.

22. @NeurosurgeryOSU. Carole Miller, MD graduated from @NeurosurgeryOSU in '71. She dominated as: 4th female ABNS-certified neurosurgeon, 1st female member in SNS, 1st female president of NSA and 1st female director of an accredited NS residency program. Proud of our legacy of female graduates! \#NWPD. February 3, 2020. Accessed January 21, 2021. https://twitter.com/NeurosurgeryOSU/ status/1224408503499968513

23. Faces of Title IX. Dr. Alexa Canady. National Women's Law Center; 2012. Accessed January 21, 2021. https://www.nwlc. org/title-ix/alexa-canady.html

24. Changing the Face of Medicine. Dr. Alexa Irene Canady. US National Library of Medicine. Published October 14, 2003. Accessed January 21, 2021. https://cfmedicine.nlm.nih.gov/ physicians/biography_53.html

25. Canady AI. Curriculum vitae. West Florida Public Library System; 2017. Accessed January 20, 2021. http://agenda.myescambia.com/docs/2014/ REGBCC/20140603_1046/6219_Library\%20App_ Resume_060314.pdf

26. Odell T, Toor H, Takayanagi A, et al. Gender disparity in academic neurosurgery. Cureus. 2019;11(5):e4628.

27. Benzil DL, Muraszko K, Canady AI. Team building and building a reputation. In: Benzil DL, ed. Heart of a Lion, Hands of a Woman: What Women Neurosurgeons Do: Creativity in Honor of the 20th Anniversary of Women in Neurosurgery (WINS). Donning; 2009.

28. Bhat DI, Indira Devi B, Bharti K, Panda R. Cortical plasticity after brachial plexus injury and repair: a resting-state functional MRI study. Neurosurg Focus. 2017;42(3):E14.

29. Sokki AM, Bhat DI, Devi BI. Cortical reorganization following neurotization: a diffusion tensor imaging and functional magnetic resonance imaging study. Neurosurgery 2012;70(5):1305-1311.

30. Mohanty CB, Bhat DI, Devi BI. Use of animal models in peripheral nerve surgery and research. Neurol India. 2019; 67(suppl):S100-S105.

31. Kahn P. Stanford's medical alumni association honors Frances K. Conley and Augustus A. White III with the 2006 J.E. Wallace Sterling Award for Distinguished Alumni. Frances Conley: no pain, no gain. Stanford Medicine Magazine. Published 2006. Accessed January 18, 2021. http: //sm.stanford.edu/archive/stanmed/2006summer/alumniprofiles.html

32. Women in Neurosurgery. Frances K. Conley, MD. Published 2020. Accessed January 18, 2021. http://www. neurosurgerywins.org/doctor/dr-frances-conley

33. Landman A, Meisel ZF. The Robert Wood Johnson Foundation Clinical Scholars Program and emergency medicine. Acad Emerg Med. 2010;17(4):e17-e22.

34. Medical College of Wisconsin. Marjorie Wang, MD, MPH, FAANS. Published 2020. Accessed January 18, 2021. https:// www.mcw.edu/find-a-doctor/wang-marjorie

35. Parr AM. Honoring women leading the way in spinal surgery. Neurosurgery Blog. Published March 31, 2018. Accessed January 18, 2021. https://www.neurosurgeryblog. org/2018/03/31/honoring-women-leading-the-way-in-spinalsurgery/

36. Bono CM, Ghiselli G, Gilbert TJ, et al. An evidence-based clinical guideline for the diagnosis and treatment of cervical radiculopathy from degenerative disorders. Spine J. 2011; 11(1):64-72.

37. Indiana University School of Medicine. Shelly D. Timmons, MD, PhD. Published 2020. Accessed January 17, 2021. https: $/ /$ medicine.iu.edu/faculty/44883/timmons-shelly

38. Benzil DL. Changing our culture. J Neurosurg. 2014;120(5): 1212-1216.

39. Benzil DL, Abosch A, Germano I, et al. The future of neurosurgery: a white paper on the recruitment and retention of women in neurosurgery. J Neurosurg. 2008;109(3):378386.

40. Dossani RH, Terrell D, Kosty JA, et al. Gender disparities 
in academic rank achievement in neurosurgery: a critical assessment. J Neurosurg. 2020;133(6):1922-1927.

41. Durham SR, Donaldson K, Grady MS, Benzil DL. Analysis of the 1990-2007 neurosurgery residency match: does applicant gender affect neurosurgery match outcome? $J$ Neurosurg. 2018;129(2):282-289.

42. Spetzler RF. Progress of women in neurosurgery. Asian J Neurosurg. 2011;6(1):6-12.

43. Benzil DL, Saboori M, Mogilner AY, et al. Safety and efficacy of stereotactic radiosurgery for tumors of the spine. $J$ Neurosurg. 2004;101(suppl 3):413-418.

44. University of Utah. Erica F. Bisson, MD, MPH. Published 2020. Accessed January 17, 2021. https://healthcare.utah.edu/ $\mathrm{fad} / \mathrm{mddetail}$.php?physicianID $=\mathrm{u} 0577670 \&$ name $=$ erica-fbisson
45. Northwestern Medicine. Aruna Ganju, MD. Published 2020. Accessed January 17, 2021. https://www.feinberg. northwestern.edu/faculty-profiles/az/profile.html?xid=15629

46. Women in Neurosurgery. History of women in neurosurgery. Published 2020. Accessed January 17, 2021. http://www. neurosurgerywins.org/history-of-women-in-neurosurgery

47. The Ottawa Hospital. Eve Tsai. Published 2020. Accessed January 17, 2021. http://www.ohri.ca/profile/etsai

48. University of Minnesota. Ann M. Parr, MD, PhD. Published 2020. Accessed January 17, 2021. https://med.umn.edu/bio/ neurosurgery-specialties/ann-parr 